\title{
DEVELOPMENT OF A FLOTATION-SPECTROPHOTOMETRIC METHOD FOR DETERMINATION OF CETYLPYRIDINIUM CHLORIDE IN PHARMACEUTICAL PRODUCTS
}

\author{
Hooshang Parham*, Nahid Pourreza and Darioshi Moradi \\ Department of Chemistry, Faculty of Science, Shahid Chamran University, Ahvaz, Iran
}

Recebido em 17/8/10; aceito em 16/11/10; publicado na web em 18/2/11

\begin{abstract}
A new simple and sensitive flotation-spectrophotometric method for the determination of cetylpyridinium chloride (CPC) is reported. The method is based on the formation of an ion- associate between CPC and Orange II (OR) which is floated in the interface of aqueous phase and $n$-hexane by vigorous shaking. The aqueous solution was discarded and the adsorbed ion associate on to the wall of a separating funnel was dissolved in a small volume of methanol solvent and its absorbance was measured at $480 \mathrm{~nm}$. The apparent molar absorptivity $(\varepsilon)$ of the ion associate was determined to be $4.12 \times 10^{5} \mathrm{~L} \mathrm{~mol}^{-1} \mathrm{~cm}^{-1}$. The calibration graph was linear in the concentration range of $15-800 \mathrm{ng} \mathrm{mL}^{-1}$ of CPC with a correlation coefficient of 0.9988 . The limit of detection (LOD) was $10.8 \mathrm{ng}$ $\mathrm{mL}^{-1}$. The relative standard deviation (RSD) for determination of 100 and $800 \mathrm{ng} \mathrm{mL}^{-1}$ of CPC was 3.47 and $2.04 \%$ (n=7), respectively. The method was successfully applied to the determination of CPC in a commercial mouth washer product.
\end{abstract}

Keywords: flotation-spectrophotometry; cetylpyridinium chloride; Orange II.

\section{INTRODUCTION}

Flotation-spectrophotometry probably provides one of the most sensitive, relatively simple and fast approach to trace analysis. ${ }^{1}$ Ion-association systems, in a more general way, could be said to result from the interaction of charged particles or complexes with oppositely charged ions. When a quaternary ammonium containing compound is used, the primary complex produced is cation, possessing the same charge as that of a metal. Such complexes were made to associate with anionic dyes in order to be extractable from aqueous solutions. ${ }^{1}$ Cetylpyridinium chloride (CPC), a quaternary ammonium salt, is widely used in industrial and pharmaceutical products, especially in manufacturing of mouth washers, drupes and cosmetics.

Cetylpyridinium is generally determined in pharmaceutical and cosmetic products by high performance liquid chromatography, ${ }^{2}$ ion-pair extraction-TLC, ${ }^{3}$ ion-pair extraction-spectrophotometry, ${ }^{4}$ chemiluminescence, ${ }^{5}$ potentiometric ${ }^{6,7}$ and spectrophotometry. ${ }^{8}$ Using anionic dyes as counter ions are also examined. ${ }^{9-17}$ The accuracy of these analytical methods is determined by the distribution constant of ion-pair between the organic and aqueous phases. For insufficiently high distribution constants, extraction must be repeated several times. More recently, capillary electrophoresis (CE) has been employed for the analysis of cationic surfactants. ${ }^{18-20}$

In this paper, we present a flotation-spectrophotometric method for quantitative determination of Cetylpyridinium chloride (CPC), based on its ion associate formation with OR and then the extraction of $\mathrm{CPC}^{+}-\mathrm{OR}^{-}$ion-pair into the interface between aqueous and n-hexane phase by flotation method. The method proposed has been successfully applied to the determination of cetylpyridinium chloride in pharmaceutical products.

\footnotetext{
*e-mail: hoparham@yahoo.com
}

\section{EXPERIMENTAL}

\section{Apparatus}

The absorption spectra were recorded on a JASCO model 7850 UV-Vis recording spectrophotometer and a Perkin-Elmer model 550S spectrophotometer was used for absorbance measurements. A Metrohm model $632 \mathrm{pH}$-meter with a combined glass electrode was used for $\mathrm{pH}$ measurements.

\section{Reagents}

Unless otherwise stated, all commercial reagents used were of analytical grades without further purification.

$100 \mu \mathrm{g} \mathrm{mL}^{-1}$ stock solution of Cetylpyridinium chloride (CPC) was prepared by dissolving $100 \mathrm{mg}$ of CPC (Merck) in freshly distilled water and diluting to the mark in a $1000 \mathrm{~mL}$ volumetric flask.

Stock solution of $4 \times 10^{-5} \mathrm{~mol} \mathrm{~L}^{-1}$ of OR was prepared by dissolving $0.0140 \mathrm{~g}$ of OR (Merck) in distilled water and diluting to $1000 \mathrm{~mL}$ in a flask.

Different buffer solutions (formate, phosphate and acetate) in the $\mathrm{pH}$ range of 2-8 were made by mixing $100 \mathrm{~mL}^{\circ} 0.2 \mathrm{~mol} \mathrm{~L}^{-1}$ solutions of acids with appropriate volumes of $0.2 \mathrm{~mol} \mathrm{~L}^{-1}$ solution of sodium hydroxide and adjusting the $\mathrm{pH}$ to desired value using a $\mathrm{pH}$ meter.

\section{Recommended procedure}

An aliquot of a sample solution containing up to $80 \mu \mathrm{g}$ of CPC was transferred into a $100 \mathrm{~mL}$ volumetric flask, $3 \mathrm{~mL}$ of $4 \times 10^{-5}$ mol L ${ }^{-1}$ of OR, $1 \mathrm{~mL}$ of acetate buffer $\mathrm{pH} 4$ was added and diluted to the mark with water and let stand for about $15 \mathrm{~min}$. Then the content of the flask was transferred to a $100 \mathrm{~mL}$ separating funnel containing $5 \mathrm{~mL}$ of $\mathrm{n}$-hexane and shaken violently for $75 \mathrm{~s}$. It was allowed to stand for $5 \mathrm{~min}$. After discarding the aqueous phase $2.5 \mathrm{~mL}$ of methanol was added to dissolve the ion associate 
(color solid) floated on the interface. The methanol phase extracts the solid ion associate from n-hexane phase and dissolves it completely. The absorbance of extracted colored ion associate was measured at $480 \mathrm{~nm}$ using $1 \mathrm{~cm}$ cell against a reagent blank. All experiments were carried out at room temperature.

\section{RESULTS AND DISCUSSION}

It was found that $\mathrm{CPC}$ interacts with $\mathrm{OR}$ and forms a solid ion associate which is insoluble in aqueous and highly non-polar organic phases, but soluble in some polar organic solvents such as methanol. The absorption spectrum of the dissolved $\mathrm{CPC}^{+}-\mathrm{OR}$ ion associate in methanol is shown in Figure 1. The maximum absorbance is found to be at $480 \mathrm{~nm}$. The stoichiometry of the ion pair was determined using the continuous variation method. The mol ratio of the ion associate was 1:1, and in agreement with the literature. ${ }^{13}$

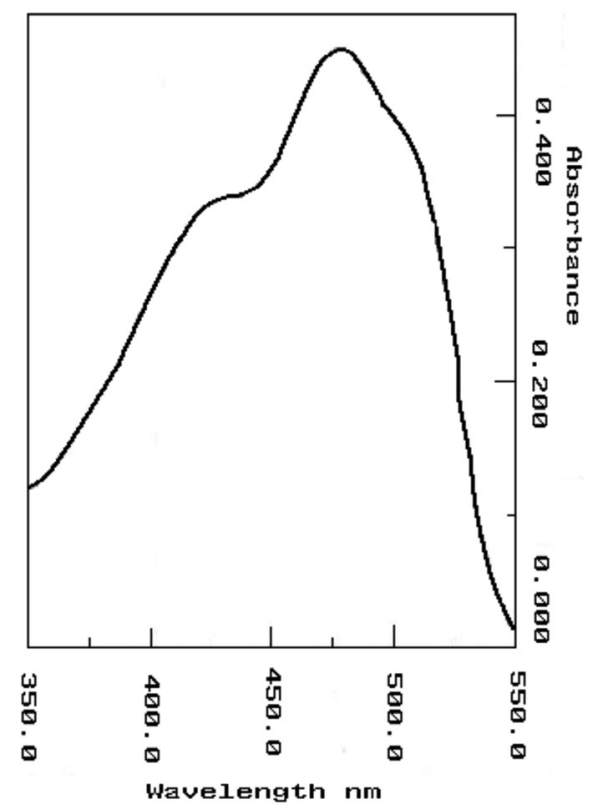

Figure 1. The absorption spectra of the dissolved $\mathrm{CPC}^{+}-\mathrm{OR}$ ion associate after extraction in methanol against a related blank. Conditions: $500 \mathrm{ng} \mathrm{mL}^{-1}$ of CPC; $1.0 \times 10^{-6} \mathrm{~mol} \mathrm{~L}^{-1}$ of OR; standing time of $10 \mathrm{~min}$; methanol, $2.5 \mathrm{~mL}$

\section{Solvent choice}

Various organic solvents such as methyl ethyl ketone, carbon tetrachloride, benzene and $\mathrm{n}$-hexane were examined. Among these, n-hexane showed good characteristics as a flotation dissolvent. Since the ion associated solid floats at the n-hexane-water interface and adheres on the funnel wall, the aqueous phase can be easily discarded completely and then by adding $2.5 \mathrm{~mL}$ of methanol to the separating funnel the solid ion associate is extracted into the methanol phase. The n-hexane in the separating funnel can be immediately used cyclically without any treatment. The volume effect of the n-hexane on the flotation process was examined in the range of 5-25 $\mathrm{mL}$ and the results showed no influence on the determination process of CPC.

Among different organic solvents such as acetone, ethanol, methyl ethyl ketone, THF and methanol examined to dissolve the adhered ion associates from the wall of the separating funnel, the dissolution of the ion associate with methanol is almost perfect.

\section{Effect of pH}

The influence of solution $\mathrm{pH}$ on the flotation of $\mathrm{CPC}^{+}-\mathrm{OR}^{-}$ion associate was studied by varying the $\mathrm{pH}$ in the range of 2.0 to 8.0, before the organic phase addition (Figure 2). The $\mathrm{pH}$ was adjusted to the desired value using formate, acetate or phosphate buffers. The maximum flotation was observed at $\mathrm{pH}=4.0$, using acetate buffer and which was selected as optimum $\mathrm{pH}$ value. It must be mentioned that the protonation of sulfonate group of the dye in $\mathrm{pH}$ values lower than 4 causes low $\mathrm{CPC}^{+}-\mathrm{OR}^{-}$ion associate formation and also competition of phosphate anion with dye anion to form ion associate with CPC causes low association of OR with CPC at $\mathrm{pH}$ values greater than 4 .

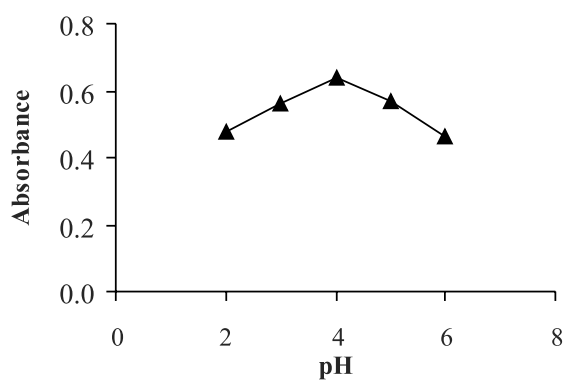

Figure 2. The influence of solution $\mathrm{pH}$ on the flotation of $\mathrm{CPC}^{+}-\mathrm{OR}$ ion as-

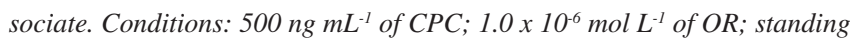
time of $10 \mathrm{~min}$; methanol, $2.5 \mathrm{~mL}$

The effect of acetate buffer concentration on the flotation of ion associate was investigated and the results showed that $1.0 \mathrm{x}$ $10^{-3} \mathrm{M}(1 \mathrm{~mL}$ of $0.01 \mathrm{M}$ in $10 \mathrm{~mL}$ solution) of acetate buffer in the final solution is enough for the system under study. Higher concentrations of buffer show no effect on the flotation process of $\mathrm{CPC}^{+}-\mathrm{OR}^{-}$ion associate.

\section{Effect of orange II concentration}

The effect of OR dye concentration used for the flotation of CPC was examined by varying the amounts of OR in the test solution. The results are shown in Figure 3. As it is observed the absorbance increased with increasing OR concentration up to 1.2 $\mathrm{x} 10^{-6} \mathrm{~mol} \mathrm{~L}^{-1}$ of OR in the final solution and then decreased. The decrease in the absorbance of the ion associate is due to increase of extracted related blank absorbance.

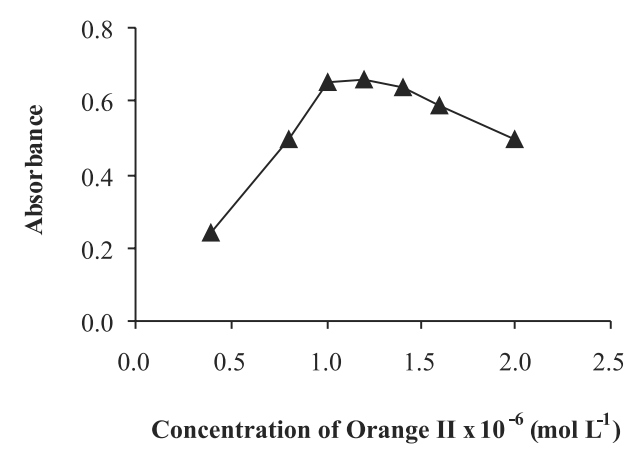

Figure 3. The effect of OR anionic dye concentration used for the flotation of CPC. Conditions: $500 \mathrm{ng} m \mathrm{~m}$ of CPC; $\mathrm{pH} 4$ (acetate buffer); standing time of $15 \mathrm{~min}$; methanol, $2.5 \mathrm{~mL}$ 


\section{Effect of standing time}

The effect of standing time on the ion associate formation was studied over the time period of 5-30 min for $0.5 \mu \mathrm{g} \mathrm{mL} \mathrm{m}^{-1}$ of CPC and $1.2 \times 10^{-6} \mathrm{~mol} \mathrm{~L}^{-1}$ of OR concentrations at $\mathrm{pH} 4.0$ of solution and then by measuring the absorbance at $480 \mathrm{~nm}$ after flotation. From the results shown in Figure 4 standing time of 10 min was chosen as the optimum standing time for ion associate formation.

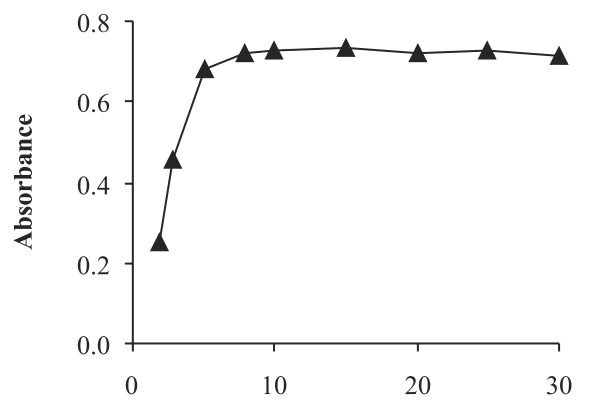

Standing time for ion association formation (min)

Figure 4. The effect of standing time on the $\mathrm{CPC}^{+}-\mathrm{OR}$ - ion associate formation. Conditions: $500 \mathrm{ng} \mathrm{mL}^{-1}$ of $\mathrm{CPC} ; 1.2 \times 10^{-6} \mathrm{~mol} \mathrm{~L}^{-1}$ of OR; $\mathrm{pH} 4$ (acetate buffer); standing time of $10 \mathrm{~min}$; methanol, $2.5 \mathrm{~mL}$

\section{Effect of electrolyte concentration}

The effect of electrolyte concentration on the ion association of CPC with OR was examined by varying the amounts of $0.1 \mathrm{~mol} \mathrm{~L}^{-1}$ of $\mathrm{NaCl}$ or $\mathrm{NaNO}_{3}$ solutions separately. The absorbance intensity of ion associate was decreased by increasing the concentration of $\mathrm{NaCl}$ or $\mathrm{NaNO}_{3}$. An increase in the electrolyte concentration will decrease the effectiveness of flotation of $\mathrm{CPC}^{+}-\mathrm{OR}^{-}$, probably because of competition between $\mathrm{OR}$ and the other anions for association with CPC.

\section{Effect of shaking time}

The flotation of the ion associate may also be influenced by the shaking time, because of increase in the surface of the gas-liquid interface. Maximum absorbance was obtained at $75 \mathrm{~s}$ shaking time.

\section{Quantitative results}

A calibration graph for the determination of CPC was constructed under optimum experimental conditions described above. Beer's law was obeyed over the concentration range of 15-800 $\mathrm{ng} \mathrm{mL}^{-1}$ of CPC with a correlation coefficient of 0.9988 at $480 \mathrm{~nm}$. The regression equation obtained by the least square method is $\mathrm{A}=1.23 \times 10^{-3} \mathrm{C}_{\mathrm{CPC}}$ - 0.022 for determination of CPC, where $\mathrm{A}$ is the absorbance and $\mathrm{C}_{\mathrm{CPC}}$ shows the concentration of $\mathrm{CPC}$ in $\mathrm{ng} \mathrm{mL}^{-1}$. With regard to the preconcentration factor of the process (40 fold, i.e., from $100 \mathrm{~mL}$ aqueous solution to $2.5 \mathrm{~mL}$ of methanol), and a path length of $1 \mathrm{~cm}$, the conditional molar absorptivity was $4.12 \times 10^{5} \mathrm{~L} \mathrm{~mol}^{-1} \mathrm{~cm}^{-1}$ at the above wavelength. The relative standard deviation (RSD) for 800 and $100 \mathrm{ng} \mathrm{mL}^{-1}$ of CPC were 2.04 and $3.47 \%(\mathrm{n}=7)$, respectively. The limit of detection (LOD) was $10.8 \mathrm{ng} \mathrm{mL}^{-1}$ based on $3 \mathrm{~S}_{\mathrm{b}}{ }^{21}$

\section{Effect of interferences}

In order to study the influence of various cations and anions on the determination of CPC, a fixed concentration of CPC, 500 $\mathrm{ng} \mathrm{mL}^{-1}$, was taken with different amounts of foreign ions and the recommended procedure was followed. A relative error of 5\% with respect to the absorbance difference for the $\mathrm{CPC}$ solution was considered tolerable. Tolerance limits are as follows: $\mathrm{Cl}^{-}, \mathrm{NO}_{3}^{-}$, $\mathrm{K}^{+}$(100 folds); $\mathrm{SO}_{4}^{2-}, \mathrm{Ca}^{2+}, \mathrm{Ba}^{2+}, \mathrm{Sr}^{2+}, \mathrm{Mg}^{2+}, \mathrm{K}^{+}, \mathrm{Li}^{+}, \mathrm{Cu}^{2+}, \mathrm{Zn}^{2+}$, $\mathrm{Cd}^{2+}, \mathrm{Ni}^{2+}, \mathrm{Co}^{2+}, \mathrm{Pb}^{2+}, \mathrm{Mn}^{2+}, \mathrm{NH}_{4}^{+}, \mathrm{Cr}^{3+}$, tartarate, citrate, EDTA (50 folds). The results show that most of the cations and anions used have no considerable effect on the determination of CPC.

\section{APPLICATION}

The proposed method was applied to the determination of CPC content of mouth washer pharmaceutical product (Daruo Pakhsh Co, Iran). A portion of the pharmaceutical solution containing up to $80 \mu \mathrm{g}$ of CPC was transferred into a $100 \mathrm{~mL}$ volumetric flask and the procedures was followed under optimum conditions. The results are shown in Table 1. As it is seen, there is a good agreement between the results of the proposed method and the reference value of CPC content $\left(500 \mu \mathrm{g} \mathrm{mL}^{-1}\right)$ of the formulation. There was no significant difference between the obtained average (485.2 $\left.\mu \mathrm{g} \mathrm{mL}^{-1}\right)$ and the reference value by performing t-test at $95 \%$ confidence.

Table 1. Determination of CPC in mouth washer pharmaceutical (from Daruo Pakhsh Co: $500 \mu \mathrm{g} \mathrm{mL}^{-1}$ ) using standard addition method

\begin{tabular}{lcccc}
\hline Sample No & \multicolumn{2}{c}{$\mathrm{CPC}\left(\mathrm{ng} \mathrm{mL}^{-1}\right)^{\mathrm{a}}$} & \%Recovery & $\begin{array}{c}\text { Original sample } \\
\left(\mu \mathrm{mL}^{-1}\right)\end{array}$ \\
\hline 1 & added & found & & 485 \\
2 & - & 48.5 & 97.0 & 490 \\
3 & 20 & 69.0 & 102.5 & 496 \\
4 & 50 & 99.6 & 102.2 & 470 \\
\hline
\end{tabular}

${ }^{\mathrm{a}}$ Average of 3 determinations

\section{CONCLUSION}

The proposed method is simple, rapid, reproducible and highly sensitive and can be applied for quality control of pharmaceutical formulations containing CPC as a surfactant. Method shows good sensitivity due to high molar absorptivity character of Orange II dye and gave a wide linear dynamic range with respect to reported methods. In the case of working with large sample volume solutions of about $100 \mathrm{~mL}$ and also small extracting solvent volume (methanol) of $2.5 \mathrm{~mL}$; a forty fold enrichment (preconcentration) factor is achieved. The limit of detection of the proposed method is better or comparable with most of the published methods s $^{2,5-8,17}$ for the determination of CPC and it can certainly be placed among the most sensitive ones.

\section{ACKNOWLEDGEMENT}

The authors gratefully acknowledge the financial support of this work by Shahid Chamran University Research Council.

\section{REFERENCES}

1. Hosseini, M. S.; Naseri, Y.; Anal. Sci. 2003, 19, 1505.

2. Wang, J.; Lu, J.; Zhang, L.; Hu, Y.; J. Pharm. Biomed. Anal. 2003, 327, 381.

3. Sakai, T.; Ohsugi, Y.; Kamoto, T.; Ohno, N.; Sasaki, H.; Bunseki-kagaka 1987, 37, 335. 
4. Nuti, V.; Bertini, D.; Farmaco 1987, 42, 335.

5. Safavi, A.; Karimi, M. A.; Anal. Chim. Acta 2002, 468, 53.

6. Baptista, P. S. C.; Araujo, A. N.; Montenegro, M. D. C. B. S. M.; Quim. Nova 2003, 26, 475.

7. Mohamed, G. G.; Ali, T. A.; El-Shahat, M. F.; Al-Sabagh, A. M.; Migahed, M. A.; Khaled, E.; Anal. Chim. Acta 2010, 673, 79.

8. Agrawal, K.; Agnihotri, G.; Shrivas, K.; Mundhara, G. L.; Patel, K. S.; Hoffmann, P.; Microchim. Acta 2004, 147, 273.

9. Kamaya, M.; Tomizawa, Y.; Nagashima, K; Anal. Chim. Acta 1998, 362, 157.

10. Nakamura, E.; Ishiwata, K.; Namiki, H.; Bunseki-Kagaku 1990, 39, 845.

11. Tsubouchi, M.; Bull. Chem. Soc. Jpn. 1971, 44, 1560.
12. Kamaga, M.; Kaneko, Y.; Nagashima, K.; Anal. Chim. Acta 1999, 384, 215.

13. Scott, G. V.; Anal. Chem. 1968, 40, 768.

14. Motomiza, S.; Gao, Y.; Microchem. J. 1994, 49, 326.

15. Irving, H. M. N. H.; Matkham, J. J.; Anal. Chim. Acta 1967, 39, 7.

16. Rosendrofora, J.; Cermakova, L.; Talanta 1980, 27, 705.

17. Ensafi, A. A.; Hemmateenejad, B.; Barzegar, S., Spectrochim. Acta, Part A 2009, 73, 794 .

18. Hcining, K.; Vogt, C.; Electrophoresis 1999, 20, 3311.

19. Taylor, R. B.; Toasaksiri, S.; Reid, R. G.; J. Chromatogr., A 1998, 789, 335.

20. Oztekin, N.; Erim, F. B.; J. Pharm. Biomed. Anal. 2005, 37, 1121.

21. Miller, J. C.; Miller, J. N.; Statistics for Analytical Chemistry, Ellis Horwood, 1984 